\title{
A CAUSE AMONG CAUSES? GOD ACTING IN THE NATURAL WORLD
}

\section{IGNACIO SILVA}

University of Oxford

\begin{abstract}
Contemporary debates on divine action tend to focus on finding a space in nature where there would be no natural causes, where nature offers indeterminacy, openness, and potentiality, to place God's action. These places are found through the natural sciences, in particular quantum mechanics. God's action is then located in those ontological 'causal-gaps' offered by certain interpretations of quantum mechanics. In this view, God would determine what is left underdetermined in nature without disrupting the laws of nature. These contemporary proposals evidence at least two unexamined assumptions, which frame the discussion in such a way that they portray God as acting as a secondary cause or a 'cause among causes'. God is somewhat required to act within these 'gaps', binding God to the laws of nature, and placing God's action at the level of secondary causes. I suggest that understanding God's action, following Thomas Aquinas, in terms of primary and secondary causation could help dissolve this difficulty. Aquinas moves away from this objection by suggesting to speak of an analogical notion of cause, allowing for an analogical understanding of God's causality in nature. With a radically different understanding of the interplay between secondary causes and God, Aquinas manages to avoid conceiving God as a cause among causes, keeping the distinctive transcendent character of God's causality safe from objections.
\end{abstract}

On the face of it, the idea of God acting directly in nature brings intellectual challenges both to philosophers and theologians, since it would appear to undermine nature's common course. Nevertheless, it seems necessary to formulate an account on how it is possible to understand that nature has its own laws and regular activities together with the claim that God can participate actively in the production of natural effects. After all, the God of Judaism, Christianity, and Islam is 
not a God of the side-lines. Their God is a God who acts in particular and special ways in the individual lives of human beings throughout history. It is crucial, then, for theologians and philosophers of religion to provide believers with an intellectually viable account of divine action in the universe.

The dilemma of God's action in nature could be stated thus: were God to intervene in nature, He would be breaking, suspending or simply not following the apparent lawful order that He created in the universe, which would, at least for some, imply an inconsistency in God's nature. ${ }^{1}$ Furthermore, this situation would seem to threaten the foundations of the natural sciences, since it would be impossible to discriminate between God's and nature's actions. A law-ruled universe, then, does not seem to allow for an external agent to act within it.

The change of the century, from 1990 to 2005 more specifically, saw the development of the project 'Scientific Perspectives on Divine Action', co-sponsored by the Vatican Observatory and the Centre for Theology and the Natural Sciences in Berkeley. Scholars taking part in this project discussed many innovative proposals concerning God's action in the created universe, most prominently those proposed by Robert Russell (among many others, 2006), Thomas Tracy (2012), John Polkinghorne (2001a), Arthur Peacocke (1995), Philip Clayton (1997), and Nancey Murphy (1995). Their main concern was to explain how God can be said to act within nature in ways which would develop history in the directions God wants, but without disrupting the lawful natural order. In this respect, it is important to bear in mind that most of these scholars address the question of these divine acts leaving aside the question of miracles. It is not the miracles that Russell, Tracy et al. want to explain, but rather how God can be said to guide the universe acting here and now in ways which do not disrupt the order of the universe. Thus, the notion of 'special providence' or 'special divine action' was introduced, in opposition to general divine action, which refers to the universal creation and upholding of the universe (and its lawful order) in existence. Special divine action, on the contrary, is a notion meant not to explain how God creates and sustains the universe, but rather it was used to express ways in which God guides history acting within the very laws of nature. Introducing this notion allowed these scholars to think and talk about divine action in a world described by the natural sciences without

${ }^{1}$ For example, Taede A. Smedes (2004: 39). 
reference to particular divine interventions within the course of natural events, usually referred to as miracles.

The key and novel move in their argument was to find in the current scientific theories 'places', loci, where to locate God's action: because their goal was to understand and to describe God's action in the natural world in non-intrusive terms, in a way that is complementary to the grain of nature, it was necessary to find real causal gaps in the causal order of nature within which God could act. These gaps would allow God to interact with creation without disrupting the works of nature, without breaking or intervening in its laws. Following the emergence of an indeterministic account of nature given by the development of quantum mechanics in the twentieth century, Russell, Tracy, Murphy and the others explored the possibility of understanding divine action through these indeterminacies. Thus, the indeterminism of quantum events offered these scholars the conceptual framework in which to place God's action, without disrupting the natural causal order, but determining its outcome nevertheless. Because the very laws of nature show that there are events which are open to several distinct outcomes, God could simply choose which outcome to determine without breaking those laws. This is the programme that Robert Russell named NIODA: the search for a non-interventionist, objective, divine action.

In addition to this 'quantum divine action' thesis, other proposals have also tried to use the non-deterministic character of twentieth-century science to offer non-interventionist proposals for divine action: John Polkinghorne, for example, has argued for divine action in and through chaotic systems, Arthur Peacocke suggested models of top-down divine causation, and Philip Clayton held that theories of emergence could be regarded as a viable path to think new models of divine action. All these different approaches are discussed within the five published volumes of the project, and they all deserve careful attention.

I will take Russell's quantum divine action thesis as the case study of this paper. Even after having received much criticism, Russell still holds it, counter-arguing the many objections existing in the literature. ${ }^{2}$ I believe, however, that there are some assumptions in his proposal that still need careful consideration. In few words, I contend that this way of understanding divine action requires conceiving of God acting as natural causes do, a conclusion that not many theologians would want

\footnotetext{
${ }^{2}$ See, for example, Russell (2006).
} 
to accept if God's transcendence is to be maintained. The root of this problem lays on the very notion of causality used in the contemporary debate on divine action, which I find remains also unexamined. After presenting Russell's proposal in detail and my analysis of it, I will suggest considering the issue through the thought of Thomas Aquinas. I want to suggest that his ideas on this topic, in particular his way of distinguishing the primary from secondary causes, can shed new light in our understanding of God's acting in the created universe.

\section{NIODA AND QUANTUM DIVINE ACTION}

Modern science, i.e. science from the seventeenth to the late nineteenth century, seemed to picture a purely deterministic universe, which created a dilemma for explaining, or even admitting, any kind of special divine action: were God to act, God would be breaking the laws of nature. Only general providence conceived as the creating and sustaining of the universe could be accepted. ${ }^{3}$ Russell (2007: 202) acknowledges this situation and faces it, trying to offer Christians a valid account of special divine acts. With the arrival of quantum mechanics by the end of nineteenth century, however, modern science was challenged, and a conception of a causally open and indeterministic universe began to develop, at least in its most fundamental level. This new picture of nature meant that the laws which science used to describe the behaviour of nature, at least at one level, suggested that nature presented 'ontological causal gaps' in its commonly regular behaviour.

The dilemma of divine action appeared, then, to be diluted: in an indeterministic universe God could act within nature without breaking or suspending any natural law. A description of these special divine actions, according to a non-interventionist objective divine action account, appeared to be a plausible theological tenet. Theology could once again hold that God acted in the world objectively and that God did so without intervening in, breaking, or suspending the laws of nature. In Russell's words (2006: 583):

God's special objective action is non-interventionist when it brings about events which go beyond those described by the laws of nature without contravening or disproving them, because natural efficient causality, as

${ }^{3}$ For modern scientists' views on divine action, see, for example, Peter Harrison (1995). 
described by these laws, is created by God ex nihilo, to be insufficient to bring these particular events about.

The question, then, is: how does God act through quantum events? The standard interpretation of quantum mechanics, the Copenhagen interpretation, explains that the key event in a quantum system, the collapse of the wave-function, is of an indeterministic nature. Russell (2006: 591), among many others, accepts this interpretation making the additional claim, key for my argument, that the total set of natural conditions affecting a quantum process, that is, the total set of conditions which science discovers and describes through its equations, is necessary but insufficient in principle to determine the precise outcome of the process. For Russell (2001: 293), God acts together with nature to bring about quantum events, in a way that can be understood as nature providing the necessary but insufficient causes, and God complementing with His action nature's insufficiency, in order to constitute the sufficient cause of the occurrence of the event. In this account, then, God would act purposefully within the on-going natural processes without disrupting these processes or violating the laws of nature. In addition, for Russell, because no quantum event is fully determined by natural causes, God acts in all of them, since the principle of sufficient reason requires that there are sufficient causes for each event. On certain occasions, however, God will choose to actualise one state in particular, and not the other, because that state, and not the other, conveys God's providence. In this manner, God fulfils what nature offers, providentially bringing the future which He promised for all creation, acting specifically in all events. God acts, then, objectively and directly in and through all quantum events to actualise one of the several potential outcomes.

Alvin Plantinga (2011) has lately endorsed a similar view in his latest book. He argues that because of the great challenge that quantum mechanics puts against the deterministic view of nature endorsed by most modern scientists, theologians do not face a great problem in allowing God to interact with nature. The central idea is that God acts within the quantum system at the collapse of the wave-function, much like Russell suggests. Plantinga, however, holds that the Copenhagen interpretation chosen by Russell renders God's special acts to be too episodic. Instead, he favours the Ghirardi-Rimini-Weber (GRW) interpretation, which allows for collapses to happen besides and beyond measurements. 
Plantinga explains that on this approach (2011: 116, emphases in the original):

[W]e could think of the nature of a system as dictating that collapses occur at the regular rate they in fact display. What is presently of significance, however, is that on these approaches there is no cause for a given collapse to go to the particular value (the particular position, for example) or eigenstate to which in fact it goes. That is, there is no physical cause; there is nothing in the previous physical state of the world that causes a given collapse to go to the particular eigenstate to which it does go. But of course this state of affairs might very well have a nonphysical cause. It's wholly in accord with these theories that, for any collapse and the resulting eigenstate, it is God who causes that state to result. Perhaps, then, all collapse-outcomes (as we might call them) are caused by God. If so, then between collapses, a system evolves according to the Schrödinger equation; but when a collapse occurs, it is divine agency that causes the specific collapse-outcome that ensues. On this view of God's special action - call it 'divine collapse-causation' ('DCC') - God is always acting specially, that is, always acting in ways that go beyond creation and conservation, thus obviating the problem alleged to lie in his sometimes treating the world in hands-off fashion but other times in a hands-on way.

The indeterminacy of quantum mechanics is, then both for Russell and Plantinga, what offers a solution to the special divine action problem. For them, it is God, a non-physical cause, that fulfils nature to be the cause of the collapse of the wave function.

Confronted with the question of God's causal status in comparison to that of natural causes, again both Russell and Plantinga affirm that given the ontologically indeterministic interpretation of quantum theory, science discovers that there are no sufficient natural (physical) causes for the specific quantum events, which implies that God is not a natural (physical) cause. If this were the case, Russell (2006) continues, God's action could be discovered by science. Thus, they argue, God is not acting as a natural cause and God's action remains hidden from science: where science employs quantum mechanics and philosophy points to ontological indeterminism, faith sees God acting with nature to create the future. Russell (2006: 587) states: 'If God acts together with nature to produce the event in which a radioactive nucleus decays, God is not acting as a natural, efficient cause.' 


\section{TWO UNEXAMINED ASSUMPTIONS}

I want to argue in this section that the proponents of the quantum divine action thesis are ill-assuming that causality entails determinism, and that God acting in the world means less autonomy for nature. These two assumptions are evidence of the univocity of the notion of cause being used in this debate. Hence, the claim that God does not act as a natural cause would not hold. In fact, I will argue that there is no other way to understand God's action in the world if one holds that God has to act where there's no natural cause.

First I suggest analysing how the relation between cause and effect is understood in this scenario. It seems clear that, from the perspective of the quantum divine action thesis, a cause is that which determines the outcome of the development of a physical system. Thus, according to this interpretation of the causal nexus, the mere existence of an event which can be interpreted as a cause requires the existence of an event which is interpreted as its effect. Furthermore, the effect cannot be something different from what it is, given that the cause is required to cause what it is meant to cause, in a deterministic fashion. Most authors involved in the context of the debate on divine agency in nature today would, in fact, seem to agree with these ideas.

The indeterminism found in the nature of quantum events, thus, is not understood in terms of non-deterministic causes, but rather in terms of a-causal events. There is a lack of causality, and hence a lack of determination, in nature. For Russell, Tracy, Murphy, and Plantinga, quantum mechanics brings some break in the ontological causal chain at the subatomic level of nature. Thus, future events are not caused, and hence not determined, by previous natural events. The fact that contemporary science now offers a view of nature in which there can be novelty in its development is explained by a non-causal view of causation rather than an indeterministic type of causation. This seems clear when both Russell and Plantinga affirm, for example, that nature offers insufficient causes for the collapse of the wave function: there are no natural causes sufficient to cause quantum events.

My point here is that, even if Russell, Plantinga et al. affirm that the dilemma of divine action within a deterministic universe is broken given the indeterministic character of the universe discovered in the twentieth-century, the notion of causality assumed in these discussions remains a deterministic notion. This stance means, as I will attempt to 
show in the following pages, that the notion of cause is univocal, which in the end will make God to act at the level of natural causes. Russell and Murphy, for example, assume this notion when they want to explain why it is necessary to admit that God acts in every event which is not fully determined by natural causes. They argue that, given the insufficient character of nature's causality, if events are not caused by God's action then they would have no sufficient cause, and hence they could not possibly exist. ${ }^{4}$ Therefore causes, regardless of their physical or nonphysical character, are to be thought of univocally.

Second, I find that scholars supporting the quantum divine action thesis seem to hold that were God able to act whenever and wherever God wants within the universe, the autonomy of nature in its actions would be endangered. The reason seems to be the following: there is a fundamental incompatibility between the view of God acting in the universe here and now and the universe having its own autonomous natural causal processes. In defence of the autonomy of the natural order and of the existence of real causal connections in that order, God's causal power is restricted. If there is a natural cause, then God is not acting there (and certainly could not be acting there). This notion, again, points toward the univocity of the idea of cause being used in the whole discourse about quantum divine action.

The urgency to find adequate ways to account for God's activity in the world without denying nature's proper autonomous processes seems to have forced theologians to equate God's causality with nature's causality: the only way in which God could do something within the natural realm is if there is a situation within the natural world that would have no cause, i.e. a place where nature does nothing. In these places, hence, there would be no autonomous natural action, because there would be no action at all. Therefore, were God to act in these, there would be no incompatibility between nature's autonomy and God's power.

Of course, those who hold the quantum divine action thesis to be a non-interventionist model of divine action, take an incompatibilist view regarding God's actions and natural causality: where there is natural causality, there cannot be special divine causality. In this sense, the necessity of explaining the autonomy of nature appears as an indication of some reduction in God's power or activity. If God is to act in the universe, then nature should not be acting where and when

${ }^{4}$ Russell (2006: 591); Murphy (1995: 338); Plantinga (2008: 393-395). 
God is to act. God's causal power, then, is to be restricted to those places and moments when nature lacks sufficient causal power. The notion of causality assumed in postulating the quantum divine action thesis, then, is a univocal notion which implies that a cause is that which determines the outcome of an event. Second, this very notion requires that God's causality, at least in regards to special divine actions, should not diminish nature's autonomous actions and integrity.

Given these assumptions, I argue that the quantum divine action thesis renders God to act (specially) as another created cause, or how it is commonly expressed, God is forced to act as a cause among causes, that is, as a created cause. The first issue to tackle now is the meaning of this expression. After all, everyone involved in these debates would agree that God is a cause, in at least a similar way in which created things are also causes. One should consider here that the objection that God is taken to act as a 'cause-among-causes' does not want to deny the fact that God is a cause, or to affirm that God should not be said to cause. On the contrary, this objection means that it is not a good theological move to consider God to be acting as secondary/created causes. The objection is thus making emphasis on God's upmost transcendence, stressing that when God acts, God is always causing as a primary cause, and never as a secondary, created cause. The basic idea behind this objection, then, is that God should not be placed at the level of created causes, because doing so would mean denying or diminishing God's transcendence. Certainly, this objection is not meant to deny the possibility of God acting within the created order of nature as a cause (for example in performing miracles), but to defend God's non-worldliness.

What the quantum divine action thesis tells us is, ultimately, that God is bound by the laws of nature to act in nature. God needs to find openings or causal gaps in these laws in order to act, meaning that these laws bind God to act according to them. As I said, it is the univocal notion of causality which is assumed in the whole debate about divine action that prevents any metaphysical elasticity to distinguish God's causality from natural, created causality. It is precisely because of this univocal notion that proponents of this thesis need to find places for God to act where there is no created causality. This thesis, in the end, requires one cause not to be sufficiently causing in order to have another cause complementing that act of causing. It seems evident, then, that this thesis considers both the insufficient cause and the complementing 
cause to be of the same kind, thus acknowledging the univocity of the notions of cause and causation.

In this state of affairs I see two paths to follow: 1) one can accept God to be considered as acting as a cause among causes - al la John Polkinghorne (2001b) in his kenotic considerations, where he affirmed that special divine providence is exercised as a cause among causes; or 2) one can revise and examine the assumptions. In this respect, one could a) revise the scientific data or b) look at the philosophical notions involved in the discourse about divine action. It certainly is not the task of the philosopher or the theologian to revise the work of the scientists, and thus option 2.a should be left out of consideration here. As I expressed above, option 1 does not really satisfy the traditional notions of God's transcendence, and the goal of the whole debate on divine action is to allow for the traditional transcendent God to act in the created universe: the preservation of the traditional notion of God together with the full acceptance of contemporary science appears to be the goal of all the proponents of the quantum divine action thesis. So I will follow option 2.b, considering some of Thomas Aquinas' ideas on causation and the relation between divine and creaturely, primary and secondary, causation, as to portray a picture where God's and creature's causalities interact in a non-univocal manner.

\section{AQUINAS ON GOD AS A CAUSE IN NATURE}

Thomas Aquinas dealt with the question of God as a cause in nature in several places of his work throughout his life. His main concern was to distinguish the causality of the primary cause from that of the secondary cause. I have elsewhere presented and analysed in detail his views on the relation between primary and secondary causation, so I will introduce these ideas only briefly here. ${ }^{5}$ Aquinas, however, further analyses this distinction by affirming that God cannot be considered to act as a univocal cause, but rather as an equivocal or analogical causation.

To say that one can distinguish causes analogically means, for Aquinas, that one can identify a variety of modes of causing, which would all share at least one essential feature. Thus, following Aristotle, Aquinas affirms that even if the four causes of material beings (material, formal, efficient,

${ }^{5}$ See my 'Revisiting Aquinas on Providence and Rising to the Challenge of Divine Action in Nature' (2014). 
and final) are all called causes, they cause in different ways. For Aquinas, a cause is always that upon which something depends for its being or becoming, but the modes of causality and dependency vary greatly depending on the kinds of causes involved. Each of the four different causes will cause in a particular way, being, each of them, that upon which something depends, though that dependence would be with respect to different features of the thing caused. The final cause, which receives the name of final because it is the last to be accomplished, is the aim which starts and guides the action of the efficient cause or agent. The efficient cause is that whose influx or action determines the existence of a new being: the effect. It causes by giving a new form in an already existing matter. This new form in an already existing matter is what constitutes the new being or effect. Thus matter is the subject which receives the form from the efficient cause, and the form, which is received in the matter, disposes the matter to be this or that different kind of being. In this perspective the formal cause explains why something exists as this particular kind of thing, and the material cause explains why it can cease to be what it is and become something else.

The key point here is that causality is an analogous notion which can be employed in a number of ways. A cause is always that upon which something depends for its being or becoming, but the modes of causality and dependency vary greatly depending on the kinds of causes involved. In this manner, God is also said to be that upon which everything depends, but not in any similar way to the ways which something depends on the four causes. The way in which things depend upon God is, Aquinas teaches, in their very being and existence, as I shall explain below via the four moments of God action through secondary causes. God is the primary cause of things because what God causes is the very existence of all things, without which things simply are not. The first thing, so to speak, which is required to do anything is to be. Because of this, the secondary cause cannot do anything if it is not by way of the primary cause, which brings me to the ways in which Aquinas understands how God can be said to act in nature, within the grain of the causal created order, and without disrupting this order.

To argue for this position Aquinas makes use of four different ways in which something can be said to be the cause of the action of something else. ${ }^{6}$ First, a (primary) cause can give another (secondary) cause its

\footnotetext{
${ }^{6}$ See De Pot., q. 3, a. 7.
} 
power to act. Since every operation consequent to a certain power is also said to belong to the giver of that power, and all power of any agent whatsoever is from God, God can be said to cause all the actions of nature, because he gives natural things the powers by which they are able to act, as from the first principle of all perfection. Second, God may be said to be the cause of an action by upholding the natural power in its being. God not only gave existence to things when they first began to exist, but also gives existence to them as long as they exist. So God is also always causing their causal powers. Again, God can be said to be the cause of every operation of created causes. I have called these two ways founding moments of God's acting in and through natural agents, while I have named the next two ways the dynamic moments.

The third and fourth ways depend on Aquinas' understanding of an instrumental cause. Aquinas teaches that a thing is said to cause another's action by moving it to act, as when someone applies the causal power of an instrument to action, for example when a man uses the knife's cutting power by applying its sharpness to cutting a loaf of bread or a saw to a piece of timber. For Aquinas, an instrument, when acting as an instrument, has two different effects: one which pertains to it according to its own nature, and another which pertains to it insofar as it is moved by the primary agent and that transcends its own nature. Each of these effects refers to each of the two dynamic moments of God acting in and through created causes. On the one hand, the first of these two ways of causing refers to the first action of an instrumental cause. Every agent performs its action according to its own nature and powers, moved by God to act, and to achieve its proper effect, in my example the cutting of the loaf of bread or the timber. On the other hand, the second way of causing the action of the instrument refers to the causing of an effect which goes beyond the power of any created cause, in my example, cutting the loaf of bread the shape of a star, for the joy of children (which the knife cannot do by its own power). The effect that transcends the power of the natural being when being applied by God, but which could be attained by participation in God's power, is instantiated being. ${ }^{7}$ Aquinas adds that this can only happen by the immanence of the universal power of God, the primary cause. Therefore, since the cause of an action is that by whose power that action is done, if one considers the power whereby the action is done, then the power of

${ }^{7}$ See Wippel (2007); and my 'Revisiting Aquinas'. 
the higher cause, God, is more immediate to the effect than the power of the lower cause. In these senses, then, is how Aquinas predicates to God that $\mathrm{He}$ is a cause in nature.

Even if one can say that God causes in nature, and in affirming this one is somewhat acknowledging that God and created causes cause in a similar way, i.e. in being that upon which things depend, the way in which the word 'cause' is predicated of the primary cause, God, is not the same as the way it is predicated of natural things. The use of the word 'cause' for God requires some qualification. Following his neo-Platonic analysis in his Commentary to the Book of Causes, Aquinas says, as I mentioned, that the primary cause is more influential in the effect of the secondary cause than the secondary cause itself. Given that the very being of the secondary cause is caused by the primary cause, all that the secondary cause is, is caused by the primary cause. The secondary cause is the real cause of its effect. Nevertheless, properly speaking, the primary cause is primarily the cause of the effect of the secondary cause, and then the secondary one can also be said to be a cause. Moreover, since the secondary cause does not act upon the effect except with the power of the primary cause, the effect does not proceed from the secondary cause except because of the power of the primary cause. Hence, the power of the primary cause, rather than that of the secondary cause, attains firstly to the effect.

These features of God's causality mean, Aquinas argues, that God's causation should not be thought of as a univocal cause, like when an animal generates another animal of the same species or when a quantum system produces a quantum event. Rather, Aquinas regards God's causation as analogical causation (or equivocal causation sometimes. It does not matter much for my argument which of these options Aquinas preferred at his time.) What really matters here is that for him God does not cause univocally. As Rudi Te Velde explains, 'the creature is the same as God but differently. While God is his being, the creature only participates in being, and thus possesses being. ${ }^{8}$ God's effect falls short with respect to the perfection of its cause. The effect receives a diminished and remote likeness of God, although there is still an intelligible connection between cause and effect. Commenting on these ideas, William Stoeger and John Wippel emphasise that Aquinas' model of primary and secondary causes was developed precisely to stress that when one refers to God as

${ }^{8}$ Te Velde (2006: 114). See also, In I Sent, d. 8, q. 1, a. 2, co. 
a cause, it is in a way which is unlike any other created cause, in a way that transcends what one can say or predicate about God. ${ }^{9}$

God, then, is said to be the cause of everything's action inasmuch as He gives everything the power to act and preserves that power in being (founding moments), and applies it to action inasmuch as by His power every other causal power acts (dynamic moments). This doctrine, however, should be understood in the sense that the causal powers of a natural thing suffice for being true causes in their own order, while requiring divine power to act, since God and the natural agents act on two different levels. Here is precisely where Aquinas' thought distinguishes from that of the scholars holding the quantum divine action thesis. The same effect, for Aquinas, is ascribed to a natural cause and to God, not as if God were complementing the lack of causal power in the natural cause, or the insufficiency of causality. It is not that part of the effect is performed by God and a part by the natural cause. Rather, for Aquinas the whole effect proceeds both from God and the natural cause, yet in different ways: just as the whole of the one same effect is ascribed to the instrument, and again the whole is ascribed to the principal agent.

Aquinas further argues that the operation of natural causes as secondary cause is, in a sense, necessary for God, because, even if God could produce the effect without nature, He wishes to act by means of nature in order to preserve order in things. It is not that God does not have the sufficient power to cause what He causes through natural causes. Were God willing to do so, He could. God, however, acts through natural causes because of the immensity of His goodness, by which He decides to communicate His similitude to things, not only in their existence, but also in their being causes of other things. Finally, this providential action is to be understood in the terms of the contemporary debate's special providential action, since it is an action which God does willingly here and now, when each natural agent acts, at any given time and place. Aquinas does not want to give away with the idea that God is involved in the actual working of the universe, and offers a complex analysis of the relations between the primary and secondary causes, in which the effect is produced by both the first and the secondary cause. This account of God's activity in nature helps to explain not only how God is profoundly involved in the course of nature, but also to understand the reason nature works at all.

${ }^{9}$ Stoeger (2008: 232) and Wippel (2000: 117). 


\section{CONCLUSION}

My suggestion is that the problems with the quantum divine action thesis arise because the debate on special divine action and contemporary science, and in particular the quantum divine action thesis, is working with a univocal notion of causality, which prevents any metaphysical elasticity to differentiate God's causality from natural, created, causality. Following Aquinas' analogical use of the notion of cause to refer to God and to natural beings, we are able to distinguish different created causes from the divine cause.

The quantum divine action thesis proponents, however, by trying to engage with the notions of causality which science presents in a univocal, loose flexibility to speak about God's action in the world. In the end, this is the ultimate reason for which God is considered to be acting as a natural cause. This is, as I suggest, a univocal notion which is both applied to God and to creatures, rendering God to act as a cause among causes. If the choice is to maintain a traditional notion of God, then I believe that we need to analyse, reflect, and evaluate those unexamined philosophical assumptions, in particular those about causality, which make it unavoidable to speak of a change in the notion of God.

\section{BIBLIOGRAPHY}

Clayton, Philip. 1997. God and Contemporary Science (Edinburgh: Edinburgh University Press)

Murphy, Nancey. 1995. 'Divine Action in the Natural Order', in Russell et al. (eds), Chaos and Complexity: Scientific Perspectives on Divine Action (Vatican City-Berkeley: Vatican Observatory-CTNS), pp. 325-357

Peacocke, Arthur. 1995. 'God's Interaction with the World: The Implications of Deterministic Chaos and of Interconnected and Interdependent Complexity in Chaos and Complexity', in Russell et al. (eds), Chaos and Complexity: Scientific Perspectives on Divine Action (Vatican City-Berkeley: Vatican Observatory-CTNS), pp. 263-288

Peter Harrison. 1995. 'Newtonian Science, Miracles, and the Laws of Nature', Journal of the History of Ideas, 56 (4): 531-553

Plantinga, Alvin. 2008. 'What is "Intervention"?', Theology and Science, 6 (4): 369-401

Plantinga, Alvin. 2011. Where the Conflict Really Lies: Science, Religion, and Naturalism (Oxford: Oxford University Press) 
Polkinghorne, John. 2001a. 'Physical Process, Quantum Events, and Divine Agency', in Russell et al. (eds), Quantum Mechanics: Scientific Perspectives on Divine Action (Vatican City-Berkeley: Vatican Observatory-CTNS), pp. 181-190

Polkinghorne, John. 2001b. 'Kenotic Creation and Divine Action', in John Polkinghorne (ed.), The Work of Love (London: SPCK), pp. 90-106

Robert Russell. 2001. 'Divine Action and Quantum Mechanics: a Fresh Assessment', in Russell et al. (eds), Quantum Mechanics: Scientific Perspectives on Divine Action (Vatican City-Berkeley: Vatican Observatory-CTNS), pp. 293-328

Russell, Robert John. 2006. 'Quantum Physics and the Theology of NonInterventionist Objective Divine Action', in Philip Clayton (ed.), The Oxford Handbook of Religion and Science (Oxford: Oxford University Press), pp. 579-595

Russell, Robert. 2007. 'Five Key Topics on the Frontier of Theology and Science Today', Dialog: a Journal of Theology, 46 (3): 199-207

Silva, Ignacio. 2014. 'Revisiting Aquinas on Providence and Rising to the Challenge of Divine Action in Nature', The Journal of Religion, 94 (3): 277291

Stoeger, William, SJ. 2008. 'Conceiving Divine Action in a Dynamic Universe', in Russell et al. (eds.), Scientific Perspectives on Divine Action: Twenty Years of Challenge and Progress (Vatican City-Berkeley: Vatican ObservatoryCTNS), pp. 225-247

Smedes, Taede A. 2004. Chaos, Complexity, and God:Divine Action and Scientism (Leuven, Paris, and Dudley, Mass.: Peeters)

Te Velde, Rudi. 2006. Aquinas on God: The 'Divine Science' of the Summa Theologiae (Aldershot: Ashgate)

Tracy, Thomas. 2012. 'Scientific Vetoes and the Hands-Off God: Can We Say that God Acts in History?', Theology and Science, 10 (1): 55-80

Wippel, John F. 2000. The Metaphysical Thought of Thomas Aquinas: From Finite Being to Uncreated Being (Washington, DC: The Catholic University of America Press)

Wippel, John F. 2007. 'Thomas Aquinas on Creatures as Causes of esse', in his Metaphysical Themes in Thomas Aquinas II (Washington DC: CUA Press), pp. $172-193$ 